Meta

Journal des traducteurs

Translators' Journal

\title{
Corpus Methodologies in Literary Translation Studies: An Analysis of Speech Verbs in Four Spanish Translations of Hard Times
}

\section{Pablo Ruano}

Volume 62, numéro 1, avril 2017

URI : https://id.erudit.org/iderudit/1040468ar

DOI : https://doi.org/10.7202/1040468ar

Aller au sommaire du numéro

Éditeur(s)

Les Presses de l’Université de Montréal

ISSN

0026-0452 (imprimé)

1492-1421 (numérique)

Découvrir la revue

Citer cet article

Ruano, P. (2017). Corpus Methodologies in Literary Translation Studies: An Analysis of Speech Verbs in Four Spanish Translations of Hard Times. Meta, 62(1), 94-113. https://doi.org/10.7202/1040468ar
Résumé de l'article

Dans cet article, nous analysons les verbes de communication et leur traduction en espagnol dans Hard Times de Dickens (1854). Outre leur fonction primaire d'introduire le dialogue, ces verbes peuvent contribuer à le caractériser. L'occurrence régulière d'un verbe de communication spécifique pour rapporter le discours direct d'un personnage fictif donné participe de la création de sa personnalité. Étant donné l'importance de leur rôle, nous avons analysé le rendu de ces verbes dans quatre versions espagnoles du roman. Nous avons pour ce faire adopté une méthodologie de corpus et nous avons utilisé un concordancier pour extraire les verbes de communication de la version originale du roman, ce qui nous a permis de procéder à une analyse approfondie, en contexte. Nous avons alors utilisé un corpus parallèle aligné comprenant les quatre versions traduites, que nous avons comparées entre elles afin d'examiner comment les verbes de communication avaient été rendus. Notre analyse a démontré qu'aucune des quatre traductions n'a totalement préservé leur valeur de caractérisation, ce qui peut affecter la perception des personnages par les lecteurs. L'utilisation de cette méthodologie de corpus contribue donc bien au domaine de la traduction littéraire.
Ce document est protégé par la loi sur le droit d'auteur. L'utilisation des services d’Érudit (y compris la reproduction) est assujettie à sa politique d'utilisation que vous pouvez consulter en ligne.

https://apropos.erudit.org/fr/usagers/politique-dutilisation/ 


\title{
Corpus Methodologies in Literary Translation Studies: An Analysis of Speech Verbs in Four Spanish Translations of Hard Times
}

\author{
PABLO RUANO \\ Universidad de Extremadura, Cáceres, Spain \\ pauruano@unex.es
}

\section{RÉSUMÉ}

Dans cet article, nous analysons les verbes de communication et leur traduction en espagnol dans Hard Times de Dickens (1854). Outre leur fonction primaire d'introduire le dialogue, ces verbes peuvent contribuer à le caractériser. L'occurrence régulière d'un verbe de communication spécifique pour rapporter le discours direct d'un personnage fictif donné participe de la création de sa personnalité. Étant donné l'importance de leur rôle, nous avons analysé le rendu de ces verbes dans quatre versions espagnoles du roman. Nous avons pour ce faire adopté une méthodologie de corpus et nous avons utilisé un concordancier pour extraire les verbes de communication de la version originale du roman, ce qui nous a permis de procéder à une analyse approfondie, en contexte. Nous avons alors utilisé un corpus parallèle aligné comprenant les quatre versions traduites, que nous avons comparées entre elles afin d'examiner comment les verbes de communication avaient été rendus. Notre analyse a démontré qu'aucune des quatre traductions n'a totalement préservé leur valeur de caractérisation, ce qui peut affecter la perception des personnages par les lecteurs. L'utilisation de cette méthodologie de corpus contribue donc bien au domaine de la traduction littéraire.

\begin{abstract}
In this article, speech verbs in Dickens's Hard Times (1854) and their translation into Spanish are analyzed. Apart from their basic function of introducing speech, these verbs can also contribute to characterization. The regular occurrence of a particular speech verb to report the direct speech of a particular character helps to create a fictional personality. Given the important role they may play, the rendering of such verbs in four Spanish versions of this novel is assessed. To do so, a corpus-based methodology has been employed. A concordancing software was used to retrieve speech verbs from the original novel, allowing their close analysis in context. Then, using an aligned parallel corpus containing the four versions, a comparison was carried out to see how they have been rendered. Evidence is provided that none of the four translations entirely preserves the characterizing value of the verbs, which may affect the way readers form impressions of characters in their minds. The use of this corpus metholodogy is thus seen to contribute to the field of literary translation studies.
\end{abstract}

\section{RESUMEN}

En este artículo se analizan los verbos de habla de la novela Hard Times (1854), de Dickens, y su traducción al español. Además de introducir discurso, estos verbos también pueden desempeñar un papel importante en términos estilísticos. El uso repetido de un verbo de habla para perfilar el estilo directo de un personaje concreto, por ejemplo, puede ayudar a caracterizarlo a través de su modo de hablar. En este artículo se analiza el traslado al español de estos verbos en cuatro traducciones diferentes. Para ello, se ha empleado una metodología de corpus. De forma más precisa, se ha recurrido a un software de concordancias para extraer los verbos de habla de la versión original de la 
novela. También se ha utilizado un corpus paralelo alineado formado por el texto inglés y las cuatro versiones españolas, que ha permitido realizar un estudio sistemático de la traducción de los verbos. Como se verá, ninguna de las cuatro traducciones conserva totalmente el valor caracterizador de estas formas verbales, lo que se materializa en una mella estilística considerable. El enfoque de corpus adoptado, finalmente, pretende contribuir a demostrar la validez de este tipo de aproximaciones en el campo de los estudios de la traducción literaria.

\section{MOTS-CLÉS/KEYWORDS/PALABRAS CLAVE}

études de corpus, traduction littéraire, verbes de communication, anglais, espagnol corpus studies, literary translation, speech verbs, English, Spanish estudios de corpus, traducción literaria, verbos de habla, inglés, español

\section{Introduction}

Over the last two decades, the use of corpus material and methodologies has notably increased in the always evolving field of translation studies, opening new avenues of analysis for the study of translated texts. This new area of research has been labeled corpus translation studies (henceforth CTS) and has adopted and developed corpus linguistic methodologies to analyze translating for descriptive and applied purposes (Laviosa 2013: 228). Baker (1993; 1995; 1996; 1999; 2000; 2004) may be considered a pioneer in this respect. She promoted the use of corpus methodologies to uncover the nature of translation as "a mediated communicative event" (Baker 1993: 243). Laviosa (1998, 2002; 2011; 2013; 2015), Bowker (2001), Granger, Lerot et al. (2003), Scarpa (2006), Anderman and Rogers (2008), Beeby, Rodríguez Inés et al. (2009), Xiao (2010), Kruger, Wallmach et al. (2011), Oakes and Ji (2012) or Sánchez Nieto (2014), to name just a few, followed in her footsteps, which has resulted in a scholarly corpus that occupies a new research niche.

This increasing use of corpus material and corpus methodologies in translation studies has reached literary translation studies too. The conflation of CTS and disciplines such as corpus stylistics has made possible the analysis of literary translations using corpus methods. For example, the translated works of Miguel de Cervantes (Ji 2012), James Joyce (Patton and Can 2012) or Tennessee Williams (Ruano San Segundo 2014) into Chinese, Turkish and Spanish respectively have been scrutinized from such a perspective. These analyses, though, are still small in number. Given that the use of corpora in literary translation studies is only a relatively recent development, scholars are constantly learning about, and refining, new methods and areas of application. In this regard, this article is meant to contribute another example to this branch of CTS. More specifically, I will analyze speech verbs in Charles Dickens's Hard Times and their translation into Spanish in four different versions -Ribera's, ${ }^{1}$ Ros's, ${ }^{2}$ Pozanco's ${ }^{3}$ and Melendo's ${ }^{4}$ - using a corpus-based methodology. ${ }^{5}$ Apart from their basic function of introducing speech, these verbs can also contribute to characterization. For example:

(1) 'Well!' blustered Mr. Bounderby, 'what's the matter? What is young Thomas in the dumps about?'

He spoke of young Thomas, but he looked at Louisa.

'We were peeping at the circus,' muttered Louisa, haughtily, without lifting up her eyes, 'and father caught us.'

$(\text { Book } 1 \text {, chapter } 4)^{6}$ 
Both blustered and muttered support the content of what is being said, thus contributing to the depiction of Mr. Bounderby and Louisa. As Culpeper (2001: 215) stresses in his model of characterization, "the way one speaks can trigger information about [...] personality," which in the case of Dickens and his well-known penchant for caricature results in certain personalities gravitating towards speech acts uttered in very particular ways. Speech verbs fulfill an important function in this respect in his novels (Ruano San Segundo forthcoming). The use of blustered in Hard Times, on the one hand, helps to project Mr. Bounderby's bad temper as well as his ineffectiveness, since the four occurrences of the verb are used to introduce his words exclusively (see section 4); muttered, on the other hand, reinforces Louisa's haughtiness and helps to single her out, since it is attached to her voice exclusively too. The use of these "workshop-vivid choices" (Lambert 1981: 15), therefore, affects the way readers form impressions of characters in their minds, and is thus another tool in Dickens's armory of techniques for characterization.

Rendering this selection of such specific speech verbs is fundamental if Dickens's style and his individualization of the fictional voices is to be preserved. Thanks to a corpus-based methodology it is possible to measure whether and to what extent translators maintain the stylistic nuances of such speech verbs: with the help of a concordancing software, verbs can be systematically retrieved from the English novel, which allows the emergence of patterns which would escape the naked eye (or trained intuition); the use of an aligned parallel corpus, in turn, allows a detailed analysis of how the original communicative acts are encoded in Spanish. As will be seen, subtle yet important stylistic differences in Pozanco's, Ribera's, Ros's and Melendo's approaches to the English text can be detected. These results will illustrate the potential of corpus-based approaches in literary translation studies.

\section{Methodology}

Before discussing the methodology as such, the scope of the study should be defined. The analysis will be limited to direct speech, the most widely used speech-representation strategy among nineteenth-century English novelists (Busse 2010). Furthermore, say, speech verb par excellence, will be left out of the analysis, since, being neutral, it cannot play a characterizing role by itself. This does not mean that it may not be important stylistically speaking. As pointed out by Caldas-Coulthard (1988: 167), a

narrator "can gloss utterances with the reporting verb 'say' plus either an adverb, an adjective, or a prepositional clause which will mark either manner or attitude," thus being able to match the accuracy and the range of details supplied by more specific choices of verbs. By itself, however, said does not characterize speech, which is why it has not been searched for and analyzed here.

As far as the search for verbs was concerned, a computer-assisted methodology was used. ${ }^{7}$ The English text was processed with the software WordSmith Tools version 6 (c) (Scott 2013). ${ }^{8}$ From a procedural standpoint, direct speech has some advantages which make the retrieval of verbs possible with such a tool: the more or less stable structural pattern (namely, subject + speech verb + projected clause) allows a systematic location of speech verbs, as described below. With very few exceptions, Dickens always follows the same two patterns when glossing his characters' words in direct speech: placing the projected clause after the projecting clause, ${ }^{9}$ with an inversion of 
the structure subject-verb (example 2), and embedding the projecting clause in the projected clause, also with the aforementioned inversion (example 3):

(2) 'Ah-h!' sighed Mrs. Sparsit again, with another melancholy shake of her head.

(Book 2, chapter 1)

(3) 'Well, then,' grumbled Tom. 'Don't begin with me.'

(Book 2, chapter 2)

These arrangements share two features that prove to be crucial in the search of verbs: (i) that Dickens places no element between the closing inverted comma in the projected clause and the speech verb and (ii) that speech verbs are almost always in the past simple tense. Bearing in mind that most ways of saying are regular (Wierzbicka 1987; Levin 1993) - with the exception of said and some other examples that will be referred to below -, their past simple occurrences will share a common characteristic: the suffix -ed. Hence, by searching for those tokens with an -ed ending which appear after an inverted comma (' ${ }^{*} e d$ in the concordance tool in WordSmith), speech verbs can be effectively isolated, as displayed in Figure 1, which shows twenty examples of the 332 hits retrieved: ${ }^{10}$

FIGURE 1

Sample of speech verbs retrieved in Hard Times after concordance search ' ${ }^{\star} e d$

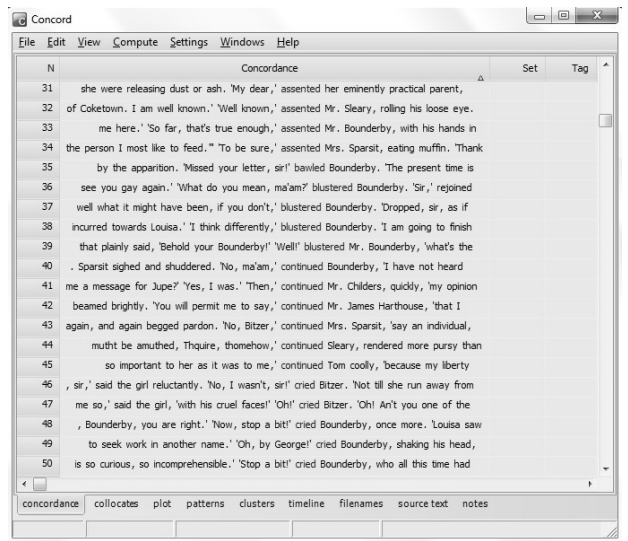

Thanks to this concordance search, every example like (2) and (3) will be found. It is true, however, that when Dickens uses a personal pronoun instead of the name of the character, the aforementioned pattern is altered, for there is no inversion of the structure subject-verb in the projecting clause:

(4) 'Halloa!' he stammered; 'I didn't know you were here.'

(Book 2, chapter 7)

To overcome this "obstacle," an alternative concordance will suffice (' he ${ }^{\star} e d$ ). Thus, apart from the search ' ${ }^{*} d$, two more searches need to be carried out, in order to locate verbs after the third-person singular male pronoun (concordance ' he ${ }^{*} e d$ ) and the third-person singular female pronoun (concordance 'she ${ }^{\star} e d$ ), as in the following examples: 
(5) 'I say!' he whispered. 'I think I can do you a good turn. Don't ask me what it is, because it may not come to anything. But there's no harm in my trying.'

(Book 2, chapter 6)

(6) 'Back agen?' she screeched, after some minutes, as if he had that moment said it. 'Yes! And back agen. Back agen ever and ever so often. Back? Yes, back. Why not?'

(Book 1, chapter 10)

Obviously, no occurrences of irregular verbs are retrieved with such concordance searches. However, this exclusion does not affect the stylistic analysis of Dickens's use of speech verbs, since most of the irregular verbs are not usually significant from a stylistic point of view. ${ }^{11}$ In fact, in the case of Hard Times, examples of only four verbs (began, put in, quoth and went on) were found on close reading. None of these contribute to characterization, since they do not characterize speech:

(7) 'I believe, sir,' quoth Mrs. Sparsit, 'you wished to see me.'

(Book 2, chapter 1)

Finally, it is also worth noting that there are examples which do not conform to the aforementioned patterns, as can be seen in examples (8) and (9):

(8) 'Yes, it was. - But isn't it the same?' she timidly asked.

(Book 1, chapter 9)

(9) 'Well? Why don't you go on?' he then asked, turning rather irritably on Stephen Blackpool.

(Book 1, chapter 11)

Such cases are, however, much less frequent than those retrieved after the concordance searches detailed above. In fact, barely thirty examples were found on close reading, a small number when compared with the 332 examples retrieved with the concordance searches detailed below (see Table 2).

Finally, as far as the search of the Spanish verbs is concerned, a manual examination following the 332 English examples retrieved suffices to identify translators' choices. An English-Spanish aligned corpus containing Hard Times and the four translations under analysis here has been used for this manual examination, which makes it possible to systematically compare how each translator renders each verb in Spanish, as shown in table $1:^{12}$

\section{TABLE 1}

\section{Excerpt from aligned corpus containing Hard Times and the four Spanish versions under} analysis

\begin{tabular}{|c|c|c|c|c|}
\hline Hard Times & J. Ribera & L. Ros & V. Pozanco & A. Melendo \\
\hline $\begin{array}{l}\text { 'Well!' blustered } \\
\text { Mr. Bounderby, } \\
\text { 'what's the matter? } \\
\text { What is young } \\
\text { Thomas in the } \\
\text { dumps about?' }\end{array}$ & $\begin{array}{l}\text {-¡Cómo! } \\
\text {-exclamó } \\
\text { Bounderby -. } \\
\text { ¿Ocurre algo? } \\
\text { ¿Por qué tiene } \\
\text { aspecto gruñón } \\
\text { nuestro Tomás? }\end{array}$ & $\begin{array}{l}\text {-¿Qué ocurre? } \\
\text {-bramó el señor } \\
\text { Bounderby- ¿A } \\
\text { qué obedece esa } \\
\text { cara de disgusto } \\
\text { del joven Tomás? }\end{array}$ & $\begin{array}{l}\text {-Vamos, vamos } \\
\text {-dijo Mr. } \\
\text { Bounderby, en } \\
\text { plan } \\
\text { perdonavidas-. } \\
\text { ¿Qué es lo que } \\
\text { han hecho? ¿A qué } \\
\text { caras tan largas, } \\
\text { Thomas? }\end{array}$ & $\begin{array}{l}\text { - ¡Vaya! - bramó } \\
\text { el señor } \\
\text { Bounderby -. } \\
\text { ¿Qué pasa? ¿A qué } \\
\text { viene esa tristeza } \\
\text { en el joven } \\
\text { Thomas? }\end{array}$ \\
\hline
\end{tabular}




\begin{tabular}{|c|c|c|c|c|}
\hline $\begin{array}{l}\text { He spoke of young } \\
\text { Thomas, but he } \\
\text { looked at Louisa. }\end{array}$ & $\begin{array}{l}\text { Hablaba del joven } \\
\text { Tomás, pero } \\
\text { contemplaba a } \\
\text { Luisa. }\end{array}$ & $\begin{array}{l}\text { Hablaba de } \\
\text { Tomás, pero } \\
\text { miraba a Luisa. }\end{array}$ & $\begin{array}{l}\text { Mr. Bounderby se } \\
\text { dirigía a Thomas } \\
\text { pero miraba a } \\
\text { Louisa. }\end{array}$ & $\begin{array}{l}\text { Hablaba del joven } \\
\text { Thomas, pero } \\
\text { miraba a Louisa. }\end{array}$ \\
\hline $\begin{array}{l}\text { 'We were peeping } \\
\text { at the circus,' } \\
\text { muttered Louisa, } \\
\text { haughtily, without } \\
\text { lifting up her eyes, } \\
\text { 'and father caught } \\
\text { us.' }\end{array}$ & $\begin{array}{l}\text {-Tratábamos de } \\
\text { ver lo que sucedía } \\
\text { en el circo } \\
\text {-murmuró Luisa } \\
\text { con voz altanera, } \\
\text { sin levantar los } \\
\text { ojos -, y papa nos } \\
\text { ha sorprendido. }\end{array}$ & $\begin{array}{l}\text { Ésta mumuró con } \\
\text { altanería, pero sin } \\
\text { levantar la vista: } \\
\text {-Estábamos } \\
\text { fisgando desde } \\
\text { fuera lo que } \\
\text { hacían en el circo, } \\
\text { y papa nos atrapó. }\end{array}$ & $\begin{array}{l}\text {-Estábamos } \\
\text { mirando el circo } \\
\text {-musitó Louisa } \\
\text { orgullosamente, } \\
\text { aunque sin } \\
\text { levantar la vista-. } \\
\text { Y padre nos pilló. }\end{array}$ & $\begin{array}{l}\text { - Estábamos } \\
\text { mirando a } \\
\text { escondidas el } \\
\text { circo -murmuró } \\
\text { Louisa con cierta } \\
\text { insolencia y sin } \\
\text { levantar los ojos -, } \\
\text { y papá nos pilló. }\end{array}$ \\
\hline
\end{tabular}

\section{Results}

The concordance searches of Hard Times retrieve a total 332 hits. These were then sorted alphabetically, yielding forty-two different verbs, as seen in Table 2:

TABLE 2

Speech verbs in Hard Times

\begin{tabular}{|l|c|l|l|l|c|}
\hline Verb & Freq. & Verb & Freq. & Verb & Freq. \\
\hline added & 5 & grumbled & 2 & retorted & 11 \\
\hline answered & 11 & hesitated & 1 & returned & 119 \\
\hline asked & 32 & inquired & 1 & roared & 1 \\
\hline assented & 4 & interrupted & 2 & screeched & 1 \\
\hline bawled & 1 & murmured & 1 & sighed & 2 \\
\hline blustered & 4 & muttered & 1 & sobbed & 1 \\
\hline continued & 7 & observed & 10 & stammered & 1 \\
\hline cried & 29 & pouted & 1 & suggested & 1 \\
\hline demanded & 1 & proceeded & 1 & urged & 3 \\
\hline ejaculated & 1 & pursued & 11 & whimpered & 4 \\
\hline enquired & 1 & rejoined & 5 & whispered & 5 \\
\hline exclaimed & 5 & remonstrated & 1 & yawned & 2 \\
\hline explained & 2 & repeated & 16 & TOTAL & 332 \\
\hline groaned & 1 & replied & 13 & & \\
\hline growled & 1 & resumed & 11 & & \\
\hline
\end{tabular}

The inventory of verbs used in Spanish by Melendo, Ros, Ribera and Pozanco is shown in table 3:

TABLE 3

Spanish speech verbs in the four Spanish translations

\begin{tabular}{|l|l|c|l|c|l|c|l|c|}
\hline & \multicolumn{2}{|c|}{ J. Ribera } & \multicolumn{2}{c|}{ L. Ros } & \multicolumn{2}{c|}{ V. Pozanco } & \multicolumn{2}{c|}{ A. Melendo } \\
\hline & Verb & Freq. & Verb & Freq. & Verb & Freq. & Verb & Freq. \\
\hline $\mathbf{1}$ & añadió & 3 & advirtió & 1 & admitió & 2 & añadió & 4 \\
\hline $\mathbf{2}$ & comentó & 1 & agregó & 2 & advirtió & 1 & asintió & 2 \\
\hline $\mathbf{3}$ & comenzó & 2 & apuntó & 3 & afeó & 2 & bramó & 1 \\
\hline $\mathbf{4}$ & contestó & 13 & asintió & 3 & añadió & 6 & chilló & 1 \\
\hline $\mathbf{5}$ & continuó & 4 & bajó la voz & 1 & aseguró & 1 & contestó & 13 \\
\hline
\end{tabular}




\begin{tabular}{|c|c|c|c|c|c|c|c|c|}
\hline 6 & convino & 1 & balbució & 1 & asintió & 4 & continuó & 10 \\
\hline 7 & dijo & 32 & bramó & 4 & atajó & 5 & dijo & 16 \\
\hline 8 & exclamó & 24 & chilló & 1 & aventuró & 1 & estalló & 1 \\
\hline 9 & expresó & 1 & clamaba & 1 & balbució & 2 & exclamó & 28 \\
\hline 10 & gritó & 5 & contestó & 79 & bramó & 1 & explicó & 2 \\
\hline 11 & gruñó & 4 & continuó & 1 & clamó & 3 & gimió & 1 \\
\hline 12 & interrumpió & 1 & cuchicheó & 3 & comentó & 2 & gimoteó & 3 \\
\hline 13 & murmuró & 4 & dijo & 19 & contestó & 14 & gritó & 6 \\
\hline 14 & observó & 3 & exclamó & 29 & continuó & 1 & gruñó & 2 \\
\hline 15 & pidió & 1 & expresó & 1 & convino & 5 & inquirió & 2 \\
\hline 16 & preguntó & 30 & fanfarroneó & 1 & correspondió & 1 & insistió & 3 \\
\hline 17 & prosiguió & 9 & gimió & 1 & corrigió & 1 & interrumpió & 2 \\
\hline 18 & refunfuñó & 1 & gimoteó & 2 & corroboró & 1 & murmuró & 2 \\
\hline 19 & repitió & 12 & gritó & 4 & dijo & 50 & observó & 10 \\
\hline 20 & replicó & 67 & gruñó & 3 & encareció & 1 & pensó & 1 \\
\hline 21 & repuso & 14 & habló & 1 & espetó & 7 & preguntó & 30 \\
\hline 22 & respondió & 35 & insistió & 2 & exclamó & 36 & prosiguió & 16 \\
\hline 23 & rugió & 1 & instó & 1 & gimoteó & 2 & reanudó & 1 \\
\hline 24 & sopló & 1 & interrumpió & 2 & gritó & 5 & reconvino & 1 \\
\hline 25 & suspiró & 2 & murmuró & 2 & gruñó & 1 & repitió & 14 \\
\hline 26 & NO TEXT & 51 & notó & 1 & inquirió & 1 & replicó & 52 \\
\hline 27 & NO MARK & 10 & preguntó & 36 & insistió & 1 & repuso & 91 \\
\hline 28 & & & prosiguió & 17 & instó & 1 & rugió & 1 \\
\hline 29 & & & reanudó & 2 & masculló & 1 & sugirió & 1 \\
\hline 30 & & & reconvino & 1 & musitó & 4 & suspiró & 2 \\
\hline 31 & & & repeated & 1 & observó & 2 & susurró & 4 \\
\hline 32 & & & repitió & 12 & pensó & 1 & tartamudeó & 1 \\
\hline 33 & & & replicó & 54 & persistió & 4 & vaciló & 1 \\
\hline 34 & & & repuso & 2 & preguntó & 26 & vociferó & 4 \\
\hline 35 & & & sentenció & 1 & prosiguió & 20 & NO MARK & 3 \\
\hline 36 & & & siguió & 1 & protestó & 2 & & \\
\hline 37 & & & suspiró & 3 & reconvino & 1 & & \\
\hline 38 & & & tartamudeó & 1 & refunfuñó & 1 & & \\
\hline 39 & & & vociferó & 1 & reiteró & 1 & & \\
\hline 40 & & & NO MARK & 30 & repitió & 4 & & \\
\hline 41 & & & & & replicó & 41 & & \\
\hline 42 & & & & & repuso & 42 & & \\
\hline 43 & & & & & rugió & 1 & & \\
\hline 44 & & & & & secundó & 1 & & \\
\hline 45 & & & & & siguió & 1 & & \\
\hline 46 & & & & & susurró & 3 & & \\
\hline 47 & & & & & terció & 1 & & \\
\hline \multirow[t]{3}{*}{48} & & & & & tronó & 2 & & \\
\hline & & & & & NO TEXT & 2 & & \\
\hline & & & & & NO MARK & 13 & & \\
\hline
\end{tabular}

The tag "NO TEXT" in Ribera's and Pozanco's inventories refers to those examples which have not been translated into Spanish because an excerpt from the origi- 
nal novel -which contains a speech verb- has been omitted. This is the case, for instance, of Ribera's translation of (10). As can be seen, he omits an excerpt of the English text (my emphasis) which contains the speech verb added:

(10) 'I really wonder, sir,' rejoined the old pupil in an argumentative manner, 'to find you taking a position so untenable. My schooling was paid for; it was a bargain; and when I came away, the bargain ended.'

It was a fundamental principle of the Gradgrind philosophy that everything was to be paid for. Nobody was ever on any account to give anybody anything, or render anybody help without purchase. Gratitude was to be abolished, and the virtues springing from it were not to be. Every inch of the existence of mankind, from birth to death, was to be a bargain across a counter. And if we didn't get to Heaven that way, it was not a politico-economical place, and we had no business there.

'I don't deny,' added Bitzer, 'that my schooling was cheap. But that comes right, sir. I was made in the cheapest market, and have to dispose of myself in the dearest.'

$\overline{\mathrm{He}}$ was a little troubled here, by Louisa and Sissy crying.

(Book 3, chapter 8)

(a) -En verdad que me extraña, caballero -replicó el ex discípulo, que era muy hábil en sus réplicas-, que tome usted en la controversia una posición que no es posible defender. Mi educación se pagó; fue un contrato pasado que quedó cumplido al dejar yo la escuela.

Al llegar a esta parte de su discurso, Bitzer quedó algo desconcertado por las lágrimas de Sissy.

(Dickens 1854/1972: 277-278, translated by Ribera)

The tag "NO MARK," on the other hand, refers to those examples where only the projected clause is preserved, thus turning direct speech instances into free direct speech instances, which results in the loss of the speech verb. For example:

(11) 'Sir,' rejoined Mrs. Sparsit, 'there was wont to be an elasticity in you which I sadly miss. Be buoyant, sir!'

(Book 2, chapter 11)

(a) -Quiero decir, señor, que antes se advertía siempre en vos una vivacidad que ahora echo yo muy en falta. ¡Alegraos, señor!

(Dickens 1854/1992: 337, translated by Ros)

Finally, as can be seen in the previous table, there is a mismatch between the number of verbs in the different inventories. As far as variety is concerned, on the one hand, Ribera uses only 25 different verbs, while Pozanco employs a greater range than even Dickens (48 examples). Regarding frequency of use, on the other, translators's inventories also present striking differences. Pozanco, for instance, uses the Spanish neutral dijo 50 times, more than any other translator. It is true that phrases and clauses may be attached to this verb to match the accuracy of more specific choices. However, translators often resort simply to a bare dijo when specific verbs are used in the original text, which affects the potential of those verbs from a characterizing point of view. These and other aspects are discussed in section 5 , but let us first ascertain the stylistic value of the English verbs so as to then focus on the most representative examples. 


\section{Characterizing role of speech verbs in Hard Times}

The stylistic analysis of Dickens's use of speech verbs that follows will be, of necessity, brief. Nevertheless, a quick look at the most specific choices suffices to discover that speech verbs play a characterizing role in Dickens's tenth novel. To begin with, many examples are used to gloss certain characters's words exclusively, thus individualizing their speeches. In the case of Louisa, she is the only character whose words are introduced by pouted, muttered and hesitated:

(12) 'That's the reason!' pouted Louisa.

(Book 1, chapter 4)

(13) 'We were peeping at the circus,' muttered Louisa, haughtily, without lifting up her eyes, 'and father caught us.'

(Book 1, chapter 4)

(14) 'I fear, father,' hesitated Louisa, 'that he must have made some representation to Stephen Blackpool - perhaps in my name, perhaps in his own - which induced him to do in good faith and honesty, what he had never done before, and to wait about the Bank those two or three nights before he left the town.'

(Book 3, chapter 7)

The use of pouted and muttered contributes to the projection of her childlike behavior. Hesitated, on the other hand, reflects her submission to her father - in fact, it is used to introduce a speech act addressed to him, as can be seen in (14).

Apart from such an individualization, some speech verbs are also repeatedly used to gloss certain characters's words. This is the case of blustered, which is not only attached to Mr. Bounderby's speech exclusively but also used on as many as four occasions to project his speech:

(15) 'Well!' blustered Mr. Bounderby, 'what's the matter? What is young Thomas in the dumps about?'

(Book 1, chapter 4)

(16) 'Here's Tom Gradgrind's daughter knows pretty well what it might have been, if you don't,' blustered Bounderby. 'Dropped, sir, as if she was shot when I told her! Never knew her do such a thing before. Does her credit, under the circumstances, in my opinion!'

(Book 2, chapter 8)

(17) 'What do you mean, ma'am?' blustered Bounderby.

(Book 2, chapter 11)

(18) 'I think differently,' blustered Bounderby.

(Book 3, chapter 3)

If we also bear in mind that roared, bawled and ejaculated introduce only Mr. Bounderby's speech too, it can be safely concluded that the way readers form an impression of Bounderby can be very much influenced by the choices used by Dickens to gloss his words:

(19) 'Missed your letter, sir!' bawled Bounderby. 'The present time is no time for letters. No man shall talk to Josiah Bounderby of Coketown about letters, with his mind in the state it's in now.'(Book 3, chapter 3) 
(20) 'Why don't you mind your own business, ma'am?' roared Bounderby. 'How dare you go and poke your officious nose into my family affairs?'

(Book 3, chapter 5)

(21) 'Nine oils, Merrylegs, missing tips, garters, banners, and Ponging, eh!' ejaculated Bounderby, with his laugh of laughs. 'Queer sort of company, too, for a man who has raised himself!'

(Book 1, chapter 6)

Whimpered is also a good example of a specific verb used repeatedly to gloss the words of a character. Although not exclusively -whimpered is used to introduce Tom's words once, as will be discussed in (38)-, Dickens uses this verb three times to characterize Mrs. Gradgrind's speech, which contributes to the projection of her faintness:

(22) 'Dear me,' whimpered Mrs. Gradgrind. 'How can you, Louisa and Thomas! I wonder at you. I declare you're enough to make one regret ever having had a family at all. I have a great mind to say I wish I hadn't. Then what would you have done, I should like to know?'

(Book 1, chapter 4)

(23) ' [...] After I have heard you myself, when the whole of my right side has been benumbed, going on with your master about combustion, and calcination, and calorification, and I may say every kind of action that could drive a poor Invalid distracted, to hear you talking in this absurd way about sparks and ashes! I wish,' whimpered Mrs. Gradgrind, taking a chair, and discharging her strongest point before succumbing under these mere shadows of facts, 'yes, I really do wish that I had never had a family, and then you would have known what it was to do without me!'

(Book 1, chapter 8)

(24) 'Oh!' said Mrs. Gradgrind, 'so you have settled it! [...]. I must give you a kiss of congratulation, Louisa; but don't touch my right shoulder, fort here's something running down it all day long. And now you see,' whimpered Mrs. Gradgrind, adjusting her shawls after the affectionate ceremony, 'I shall be worrying myself, morning, noon, and night, to know what I am to call him!'

(Book 1, chapter 15)

This verb renders her weakness and contrasts her, to some extent, to her husband, whose words - and no one else's- are introduced by groaned, which contributes to the projection of his tendency to complain:

(25) 'But look at him,' groaned Mr. Gradgrind. 'Will any coach-'

(Book 3, chapter 7)

With Tom, finally, an individualizing use of speech verbs is also observed. He is the only character whose words are glossed by growled and grumbled, which contribute to single out his speech and project his sulky character:

(26) You're a pretty article,' growled the whelp, moving uneasily in his dark corner, 'to come here with these precious imputations! You ought to be bundled out for not knowing how to behave yourself, and you would be by rights.'

(Book 3, chapter 4)

(27) 'Well, then,' grumbled Tom. 'Don't begin with me.'

(Book 2, chapter 2) 
(28) 'I don't see why,' grumbled the son. 'So many people are employed in situations of trust; so many people, out of so many, will be dishonest. I have heard you talk, a hundred times, of its being a law. How can I help laws? You have comforted others with such things, father. Comfort yourself!'

(Book 3, chapter 7)

In the light of these examples, it can hardly be denied that Dickens's use of speech verbs is far from serendipitous. Maintaining this stylistic role when translating them into another language is, therefore, fundamental, so as to preserve their characterizing value. Nevertheless, in none of the four versions analyzed here is such value entirely preserved. As will be seen, translators not only do not use a characterbounded selection of verbs, but sometimes they also do not preserve the specific manner of speaking projected by these verbs, which results in a stylistic loss from a characterizing point of view.

\section{Speech verbs in the Spanish translations}

The meaning of direct speech descriptive verbs as those analyzed here "has to do with the manner of utterances rather than matter" (Caldas-Coulthard 1987: 162). When dealing with them, therefore, translators must bear in mind that their sound component is as central as their communicative value (Faber and Sánchez 1990). The recurrence of this sound component is different in English and Spanish. In the case of English, for instance, the use of sound verbs - i.e., those related with the emission of sounds (Martínez Vázquez 2003) - with a communicative meaning is quite widespread. This is best reflected in the information supplied by dictionaries. As Martínez Vázquez claims (2003: 105), "most English sound verbs show a communicative meaning which is the result of [...] metonymy. Spanish verbs rarely show this extended meaning in dictionaries." Such a lexicographical difference between English and Spanish, though, is normally neutralized in fiction. As Rojo and Valenzuela (2001: 477) assert,

it seems to be a conventional feature of English dialogues to use profusely the general verb to say, leaving to the reader the inference of the specific role that the utterance plays in the interaction frame. On the contrary, in Spanish dialogues, the continued repetition of the general verb decir results in a lack of stylistic naturalness, and translators prefer to look for variants, by incorporating to the verb information surrounding the communicative event.

Needless to say, this description does not characterize Dickens's use of say. However, Rojo and Valenzuela's words emphasize a significant point, namely, the Spanish tendency to provide the reader with details surrounding the communicative event. Such a tendency and the fact that they found "that Spanish specific verbs of saying outnumber English ones" (Rojo and Valenzuela 2001: 473) in their corpus reveals the Spanish translators's tendency to preserve details related to the manner of speaking when translating speech verbs. It stands to reason, then, that Dickensian translators will render direct speech descriptive verbs in Spanish maintaining the wide range of details supplied by Dickens's careful choices. For example: 
(29) 'Why don't you mind your own business, ma'am?' roared Bounderby. 'How dare you go and poke your officious nose into my family affairs?'

(Book 3, chapter 5)

(a) -¿Por qué no se mete en sus propios asuntos, señora? -rugió Bounderby-. ¿Cómo se atreve a ir a meter su entrometida nariz en mis asuntos familiares?

(Dickens 1854/2005: 353, translated by Melendo)

(b) Y el señor Bounderby bramó:

-¿Por qué no os metéis en vuestros propios asuntos, ilustre señora? ¿Cómo tenéis el atrevimiento de meter vuestra indiscreta nariz en mis asuntos familiares?

Dickens 1854/1992: 401, translated by Ros)

(c) -¿¿Por qué se mete usted, señora, en lo que no le importa? -rugió Bounderby-. ¿No tiene usted bastante con sus quehaceres, que ha de meter su nariz oficiosa en los de mi familia?

(Dickens 1854/1972: 253, translated by Ribera)

(d) ¿Quién le manda meterse donde no la llaman, señora? -rugió Bounderby-. ¿Cómo se atreve a meterse en mis asuntos familiares?

(Dickens 1854/1995: 392, translated by Pozanco)

Both rugió and bramó preserve the banker's vehemence and bad mood reflected in the use of roared. They are, therefore, perfectly valid options. However, such translational accuracy is not always maintained in Melendo's, Ros's, Ribera's and Pozanco's versions. In fact, when one looks at how they translate the examples discussed in section 4 , it is discovered that in almost every case there is at least one version which does not keep the characterizing value of the English verb. This results, as will be seen next, in a stylistic loss which affects characters's portrayals. Let us start with Louisa and Dickens's exclusive use of pouted to gloss her words. Pozanco, for example, resorts to terció:

(30) 'That's the reason!' pouted Louisa.

(Book 1, chapter 4)

(a) -Esa es la razón -terció Louisa.

(Dickens 1854/1995: 34, translated by Pozanco)

The use of terciar does not maintain the childlike attitude projected by pouted. Quite on the contrary, the communicative sense of the Spanish verb alludes to a somewhat mediation on the part of the speaker, as can be seen in the definition of the verb in Diccionario de la lengua española (henceforth DRAE): ${ }^{13}$ "terciar. 9. intr. Interponerse y mediar para componer algún ajuste, disputa o discordia" (to interpose and mediate to resolve a dispute or argument; translated by the author). The use of a satellite (Rojo and Valenzuela, 2001: 471) marking Louisa's attitude, thus matching the details supplied by pouted in the English novel, would have preserved this nuance. This is a well-established practice when translating specific reporting verbs (Rojo and Valenzuela, 2001: 473) and it is, in fact, the strategy devised by Ribera, Ros and Melendo in their versions:

(b) -Precisamente por eso... -dijo Luisa con aire mohíno.

(Dickens 1854/1972: 20, translated by Ribera)

(c) -¡Por eso precisamente! -exclamó Luisa, con cara enfurruñada.

(Dickens 1854/1992: 106, translated by Ros) 
(d) -¡Por eso mismo! -dijo Louisa, torciendo el gesto.

(Dickens 1854/2005: 67, translated by Melendo)

Despite being longer constructions, they maintain the characterizing value of the original verbs, which is the key component to be preserved beyond their communicative function. Pozanco resorts to this strategy too, as can be seen in his translation of one of the four occurrences of blustered to introduce Bounderby's words:

(31) 'Well!' blustered Mr. Bounderby, 'what's the matter? What is young Thomas in the dumps about?'

(Book 1, chapter 4)

(a) -Vamos, vamos -dijo Mr. Bounderby en plan perdonavidas-. ¿Qué es lo que han hecho? ¿A qué caras tan largas, Thomas?

(Dickens 1854/1995: 33, translated by Pozanco)

Even though he could have used a verb such as bramar which would have concentrated the meaning in a specific verb (as Ros ${ }^{14}$ and Melendo ${ }^{15}$ do), this strategy is certainly better than the use of a verb which does not maintain the menacing and ineffective attitude projected by blustered, as in Ribera's use of exclamó to render the verb in Spanish:

(b) -¡Cómo! - exclamó Bounderby-. ¿Ocurre algo? ¿Por qué tiene aspecto grunón nuestro Tomás?

(Dickens 1854/1972: 19, translated by Ribera)

The verb exclamar maintains just the pitch, but not the attitude, ${ }^{16}$ which is the key aspect of Dickens's selection of blustered to gloss Bounderby's words. This loss of information is not detected in Ribera's translation of the remaining examples of blustered, though. In two of them, in fact, he resorts to a satellite too:

(32) 'Here's Tom Gradgrind's daughter knows pretty well what it might have been, if you don't,' blustered Bounderby. 'Dropped, sir, as if she was shot when I told her!'

(Book 2, chapter 8)

(a) -Aquí está la hija de Tom Gradgrind, que sabe todo lo que hubiera podido perder si usted lo ignora -sopló el huracanado Bounderby-. ¡Ha caído como herida por una bala, caballero, al anunciarle yo la cosa!

(Dickens 1854/1972: 174, translated by Ribera)

(33) 'What do you mean, ma'am?' blustered Bounderby.

(Book 2, chapter 11)

(a) -¿Qué quiere usted decir, señora? -preguntó el señor Bounderby, con voz tempestuosa.

(Dickens 1854/1972: 203, translated by Ribera)

Both sopló el huracanado Bounderby and preguntó el señor Bounderby, con voz tempestuosa maintain his attitude. It is true, though, that the regular co-occurrence of blustered $+M r$. Bounderby found in the English text is lost when such satellites are used. However, there is no denying that this strategy allows the projection of his callous attitude too. These constructions explain, to a great extent, the frequent use of dijo in the Spanish inventory shown in table 3. However, as mentioned in section 3 , translators sometimes resort simply to a bare dijo to render a specific verb which 
projects character traits. To continue with the example of Bounderby, let us have a look at Ribera's translation of ejaculated, used to introduce the banker's words exclusively. Ribera's use of dijo neutralizes Bounderby's vehemence:

(34) 'Nine oils, Merrylegs, missing tips, garters, banners, and Ponging, eh!' ejaculated Bounderby, with his laugh of laughs. 'Queer sort of company, too, for a man who has raised himself!'

(Book 1, chapter 6)

(a) -¡Nueve aceites, "Pata-alerta," meter la pata, rehusar cuatro metros de percal, efectuar contorsiones...! ¡Ha! ¡Ha! -dijo el señor Bounderby.

(Dickens 1854/1972: 31, translated by Ribera)

Estalló or exclamó, without a doubt, better preserve the brusqueness of Bounderby's words, as can be observed in Melendo's and Pozanco's versions respectively:

(b) -Nueve aceites, Merrylegs, no dar una en el clavo, aros, banderolas y saltos mortales, ija! -estalló Bounderby con su mejor carcajada-. Singular compañía, también, para un hombre que se ha hecho a sí mismo.

(Dickens 1854/2005: 84, translated by Melendo)

(c) -¡Bálsamo de nueve aceites, pies con bola, ripios, banderas y un perro que se llama Patalegre! -exclamó Bounderby con su más estentórea carcajada-. ¡Un hombre como yo en semejante compañía!

(Dickens 1854/1995: 54, translated by Pozanco)

Lázaro Ros's choice, however, may not project the banker's impetuousness appropriately, since he chooses suspiró:

(d) - ¡Nueve aceites, Patas Alegres; no dar pie con bola, cintas, banderas y morcillas! ¡Vaya, no está mal el trato con esta gente para un hombre que ha subido por su propio esfuerzo! - suspiró Bounderby, y largó luego la más típica de sus carcajadas.

(Dickens 1854/1992: 122, translated by Ros)

Suspiró is much closer to the English verb sighed than to ejaculated. It is true that suspiró indicates vehemence, but this verb may also refer to pain or pity. ${ }^{17}$ The use of a verb such as estalló, exclamó or even dijo and a satellite would have been more accurate to account for the banker's vigor.

The use of dijo to render specific verbs which mark attitude is actually more frequent than might be expected, which results in a significant loss of details that affects the stylistic value of Dickensian speech verbs in the translated versions. Let us move on to the Gradgrinds. In the case of Mr. Gradgrind, for example, Pozanco resorts to dijo to translate groaned, used by Dickens to introduce his words exclusively:

(35) 'But look at him,' groaned Mr. Gradgrind. 'Will any coach-'

(Book 3, chapter 7)

(a) -Pero...con esa pinta...- dijo Gradgrind.

(Dickens 1854/1995: 429, translated by Pozanco)

This choice neutralizes Gradgrind's attitude, subtly projected by the use of such a speech verb. Ribera, Melendo and Ros, conversely, maintain his grumpiness thanks to the use of gruñó and gimió, a much more appropriate selection of verbs: 
(b) -Pero mírele - gruñó el señor Gradgrind -. ¿Qué coche querrá...?

(Dickens 1854/1972: 274, translated by Ribera)

(c) -Pero, con ese aspecto - gimió el señor Gradgrind -, ¿querrá el coche...?

(Dickens 1854/2005: 382, translated by Melendo)

(d) -Fijaos en su estado - gimió el señor Gradgrind-. ¿Creéis que puede ir así...? (Dickens 1854/1992: 431, translated by Ros)

In the case of Mrs. Gradgrind and Dickens's repeated use of whimpered to gloss her words, a significant stylistic loss has also been detected in two translations. Melendo, on the one hand, uses dijo to render the verb in Spanish, which neutralizes her feebleness and her tendency to see herself as being victimized:

(36) 'Oh!' said Mrs. Gradgrind, 'so you have settled it! [...]. I must give you a kiss of congratulation, Louisa; but don't touch my right shoulder, fort here's something running down it all day long. And now you see,' whimpered Mrs. Gradgrind, adjusting her shawls after the affectionate ceremony, 'I shall be worrying myself, morning, noon, and night, to know what I am to call him!'

(Book 1, chapter 15)

(a) -¡Bien! -dijo la señora Gradgrind-, ya veo que lo habéis arreglado [...]. Ven a que te dé un beso de felicitación, Louisa; pero no me toques el hombre derecho, porque una molestia no me deja parar en todo el día. Y ahora ya ves - dijo la señora Gradgrind, aderezándose los mantones tras la afectuosa ceremonia-, ¡mañana, tarde y noche voy a estar preocupada por no saber cómo lo tengo que llamar!

(Dickens 1854/2005: 167, translated by Melendo)

The exact same problem is seen in Ribera's version. Although he does not use the neutral dijo, he chooses a verb (prosiguió) which barely guides the reader through her words, thus neutralizing the weakness projected by whimpered:

(b) - ¡Oh! -dijo la señora Gradgrind-, ¡has terminado ya este asunto! [...]. Voy a darte un beso de enhorabuena, Luisa; mas no me toques el hombro derecho: siento en él un dolor que me va de arriba abajo. Cásate, que ahora -prosiguió la señora Gradgrind, ajustando su chal a raíz de esta afectuosa ceremonia - tendré que devanarme los sesos, de la mañana a la noche, para saber cómo llamarle a él.

(Dickens 1854/1972: 96, translated by Ribera)

Last but not least, let us look at those examples tagged as "NO TEXT" and "NO MARK" which were referred to in section 3. The omission of verbs either because a larger excerpt of text has been omitted or because the translator gets rid of the projecting clause where the verb is may of course result in a significant loss from a characterizing point of view too. Let us take the example of Tom. As commented on in section 4 , he is the only character whose words are introduced by growled, which helps to project his resentful character. Ribera, however, skips an excerpt which includes the turn where Tom's words are introduced by this verb (my emphasis):

(37) 'And when I think,' said Rachael through her sobs, 'that the poor lad was so grateful, thinking you so good to him - when I mind that he put his hand over his hard-worken face to hide the tears that you brought up there - Oh, I hope you may be sorry, and ha' no bad cause to be it; but I don't know, I don't know!' 'You're a pretty article,' growled the whelp, moving uneasily in his dark corner, 'to come here with these precious imputations! You ought to be bundled out for not knowing how to behave yourself, and you would be by rights.' 
She said nothing in reply; and her low weeping was the only sound that was heard, until Mr. Bounderby spoke.

'Come!' said he, 'you know what you have engaged to do. You had better give your mind to that; not this.'

'Deed, I am loath,' returned Rachael, drying her eyes, 'that any here should see me like this; but I won't be seen so again. Young lady, when I had read what's put in print of Stephen - and what has just as much truth in it as if it had been put in print of you - I went straight to the Bank to say I knew where Stephen was, and to give a sure and certain promise that he should be here in two days [...].'

(Book 3, chapter 4)

(a) -Cuando pienso - dijo Rachael en medio de sus sollozos - que el pobre chico estaba tan agradecido, creyendo que usted era tan buena para él; cuando ienso que se llevó la mano al rostro fatigado, para ocultar las lágrimas a que le movieran tal acción... ¡Oh!, sí, espero que lo deplore usted, como dice, y que no tenga ningún motivo oculto para ello... ¡Más no sé, no sé!»Me da vergüenza de que se hayan ustedes visto en tal estado; pero ya ha concluido. Señora, al leer lo que se ha impreso contra Esteban (una sarta de mentiras, como si las aplicaran a usted), me dirigí a casa de la banca, para manifestar que conozco el punto en que se halla Esteban y prometer que estará aquí dentro de dos días [...].

(Dickens 1854/1972: 244, translated by Ribera)

Albeit minute, this omission results in the loss of a characterizing trait which contributes to the depiction of Tom Gradgrind in the novel. Such a loss is not perceived in Ros's, Pozanco's and Melendo's versions. They translate the excerpt where the speech verb is and translate growled either as grunó or espetó, which project the sulkiness reflected in the original text as far how the speech act is articulated:

(b) -El mequetrefe gruñó, revolviéndose intranquilo en su oscuro rincón: - ¡Buena estáis vos! ¡Venir aquí con imputaciones de esa clase...! Bien merecido tendríais que os echase a la calle por no saber comportaros debidamente

(Dickens 1854/1992: 390, translated by Ros) (c) -¡Mucha gramática parda tiene usted! -le espetó Tom, que se decidió a salir de su rincón-. ¡Atreverse a venir aquí con semejantes acusaciones! ¡Si se la pusiera en la puerta por no saber conducirse no se haría sino lo debido!

(Dickens 1854/1995: 377, translated by Pozanco) (d) -¡Buena pieza está usted hecha - gruñó el lobezno, revolviéndose intranquilo en su oscuro rincón - al venir aquí con esas preciosas imputaciones! ¡Se la tenía que despachar por no saber cómo comportarse, y le estaría muy bien!

(Dickens 1854/2005: 342, translated by Melendo)

The same loss detected in those cases where no text is found in the Spanish version can be applied to those labelled as "NO MARK." To continue with the example of Tom, Dickens also uses whimpered to introduce his words once. This verb, employed normally to gloss Mrs. Gradgrind's speech acts, has the same characterizing role when attached to Tom: it is indeed used when he plays the victim. More specifically, it is used when his guilt is about to be exposed after it is discovered that he robbed the bank and threw the blame on Stephen Blackpool:

(38) 'I suppose I must. I can't be more miserable anywhere,' whimpered the whelp, 'than I have been here, ever since I can remember. That's one thing.'

(Book 3, chapter 7) 
Ros, however, opts for omitting the projecting clause, which includes the speech verb, thus turning an instance of direct speech into an instance of free direct speech, where the narrator's interference and the characterizing potential of the verb are nullified:

(a) -Me imagino que habrá que hacer eso. De todos modos, en ninguna parte seré más desdichado de lo que he sido aquí durante todo el tiempo a que alcanzan mis recuerdos. ¡Que conste eso!

(Dickens 1854/1992: 430, translated by Ros)

Without a doubt, it seems much more accurate to translate the projecting clause and to use a verb which projects Tom's moaning through the use of a very particular way of speaking, as Ribera, Pozanco and Melendo do:

(b) - Sé que no tengo otro remedio. Por lo demás, no sé que pueda llevar en otro sitio una vida más miserable que la que llevo en éste, desde que tengo uso de razón-dijo el mequetrefe lloriqueando.

(Dickens 1854/1972: 274, translated by Ribera)

(c) - Supongo que sí. Dudo que pueda sentirme peor en cualquier otra parte de lo que aquí me siento -gimoteó el canalla- desde que tengo memoria. Así que... algo es algo.

(Dickens 1854/1995: 428, translated by Pozanco)

(d) - Supongo que sí. En ninguna parte será más desgraciado - gimoteó el lobezno- de lo que he sido aquí hasta donde me alcanza la memoria. Ésa es la verdad.

(Dickens 1854/2005: 382, translated by Melendo)

As can be observed, the omission of speech verbs affects the depiction of characters too. The number of examples under the labels "NO TEXT" and "NO MARK" is different in each version. In Melendo's, for instance, only three cases of "NO MARK" have been spotted (and none of "NO TEXT"), which makes a big difference from the ten cases of "NO MARK" and the fifty-one cases of "NO TEXT" identified in Ribera's, for example. Such a difference has a direct impact on the preservation of Dickens's style in the translated texts.

All in all, the translation of speech verbs in Hard Times into Spanish is substantially different in the four versions analyzed here. Rather than focusing on the translators's inventories of speech verbs, which differ greatly too, the analysis has concentrated on how they render those specific choices which entail a characterizing role within the story. As has been demonstrated, none of the four translators entirely preserve such a role. To a greater or lesser degree, stylistic losses were detected, which can affect the way readers form impressions of characters in their minds. It is worthy of note, however, that such losses do not seem to stem from a translational difficulty, but from translators overlooking the characterizing value of speech verbs in Dickens, since it is very difficult to glimpse their potential due to their dispersed distribution in the text.

\section{Conclusion}

Thanks to the combination of approaches from different areas of research such as corpus linguistics, corpus stylistics or corpus translation studies, the use of corpus 
methodologies to analyze translation and translating has recently reached the field of literary translation studies too. The potential of corpus methodologies in literary translation studies is, in fact, proving as effective as it is for literary stylistics at large. The use of innovative models combining quantitative and qualitative analyses of corpus materials has opened new avenues of study for translated literary works, bringing new insights into the nature of literary translation. The speech verbs under analysis here are a good example. Scattered throughout the novel, it is very difficult to appreciate their role in terms of characterization, let alone to carry out a systematic translation analysis assessing whether and to what extent such a role is maintained in four different texts. With the help of a computer-assisted methodology, though, it has been possible to gauge the varying degrees of correlation between the different Spanish versions. The use of such a methodology has shown not only the varied strategies used by translators to render speech verbs in Spanish, but also that translators do not entirely preserve the characterizing nuances of these linguistic units. In sum, this analysis has demonstrated the potential of corpus methodologies in literary translation studies, contributing another example to the still emerging CLTS (corpus literary translation studies).

\section{NOTES}

1. Dickens, Charles (1854/1972). Los tiempos difíciles. Translated from English by J. Ribera. Barcelona: Petronio.

2. Dickens, Charles (1854/1992). Tiempos difíciles para estos tiempos. Translated from English by Lázaro Ros. Madrid: Cátedra.

3. Dickens, Charles (1854/1995). Tiempos difíciles. Translated from English by Víctor Pozanco. Barcelona: Editorial Ronsel.

4. Dickens, Charles (1854/2005). Tiempos difíciles. Translated from English by Ángel Melendo. Madrid: Gredos.

5. For some of the latest analyses of Dickens's style using corpus methodologies, see for instance: Mahlberg (2013); Mahlberg, Smith et al. (2013); Stockwell and Mahlberg (2015) or Ruano San Segundo (forthcoming).

6. All quotes of Dickens (1854) throughout the paper are from a digitized version (see section 2). Therefore, page numbers will not be provided.

7. The methodological procedure that follows has already been discussed in Ruano San Segundo (forthcoming), who retrieves 17,021 speech verbs in Dickens's fourteen major novels.

8. The digitized text comes from Project Gutenberg, where it can be accessed and downloaded as a plain text file, the required format when it is processed with a software tool. The reliability of texts from Project Gutenberg is a subject open to debate. For some criticism, see Mahlberg (2013: 43-44).

9. Following the taxonomy of Systemic Functional Grammar, I will for convenience use the concepts of projecting and projected clause (Halliday 2004: 445) to refer to the narrator's and characters's voices respectively.

10. Needless to say, this concordance search may retrieve examples which are not speech verbs. As may be expected, there will be instances where, out of pure coincidence, a word with an -ed ending appears after such a sign of punctuation, as in: "Before Mr. Bounderby could reply, a young man appeared at the door, and introducing himself with the words, 'By your leaves, gentlemen!' walked in with his hands in his pockets" (Book 1, chapter 6). Such cases are easy to detect and get rid of. For convenience, the results herein shown are already polished.

11. Significance is here understood as saliency in terms of the information provided about how the speech act is realized. For example: said, told, spoke, began or went on.

12. In order to be loaded in a word processor, the four Spanish translations had to be converted into plain text files. To do so, texts were scanned and processed with an OCR (Optical Character Recognition) software (the norm for digitized texts). Needless to say, typos were found. However, they do not affect the search process, since Spanish verbs are manually located using the original English verbs as a reference. 
13. Diccionario de la lengua Española (2008). Madrid: Espasa Calpe. Visited on 4 July 2015, <http:// www.rae.es>.

14. "-¿Qué ocurre? -bramó el señor Bounderby-. ¿A qué obedece esa cara de disgusto del joven Tomás?" (Dickens 1854/1992: 66, translated by Ros)

15. “-¡Vaya! -bramó el señor Bounderby-. ¿Qué pasa? ¿A qué obedece esa tristeza en el joven Thomas?” (Dickens 1854/2005: 105, translated by Melendo)

16. The definition of exclamar in DRAE reads as follows: "exclamar. 1. intr. Emitir palabras con fuerza o vehemencia para expresar la viveza de un afecto o para dar vigor y eficacia a lo que se dice. U. t. c. tr."

17. The definition of suspirar in DRAE reads as follows: "suspirar. 1. intr. Dar suspiros" "Suspiro: "1. $\mathrm{m}$. Aspiración fuerte y prolongada seguida de una espiración, acompañada a veces de un gemido y que suele denotar pena, ansia o deseo").

\section{REFERENCES}

Anderman, Gunilla and Rogers, Margaret (2008): Incorporating Corpora: The Linguist and the Translator. Clevedon: Multilingual Matters.

BAKER, Mona (1993): Corpus linguistics and translation studies: Implications and applications. In: Mona Baker, Gill. Francis and Elena Tognini-Bonelli, eds. Text and Technology: In Honour of John Sinclair. Amsterdam: John Benjamins, 233-250.

BAKer, Mona (1995): Corpora in translation studies: An overview and some suggestions for future research. Target. 7(2):223-243.

BAKer, Mona (1996): Corpus-based translation studies: The challenges that lie ahead. In: Harold Somers, ed. Terminology, LSP and Translation: Studies in Language Engineering in Honour of Juan C. Sager. Amsterdam: John Benjamins, 567-586.

BAKER, Mona (1999): The role of corpora in investigating the linguistic behaviour of professional translators. International Journal of Corpus Linguistics. 4(2):281-298.

BAKER, Mona (2000): Towards a methodology for investigating the style of a literary translator. Target 12(2):241-266.

BAKer, Mona (2004): A corpus-based view of similarity and difference in translation. International Journal of Corpus Linguistics. 9(2):167-193.

Beeby, Allison, Rodríguez Inés, Patricia and Sánchez-Gijón, Pilar (2009): Corpus Use and Translating. Amsterdam: John Benjamins.

BowKER, Lynne. (2001): Towards a methodology for a corpus-based approach to translation evaluation. Meta 46(2):345-364

Busse, Beatrix (2010). Speech, Writing and Thought Presentation in a Corpus of NineteenthCentury English Narrative Fiction. Bern: University of Bern.

Caldas-Coulthard, Carmen Rosa (1987): Reported speech in written narrative texts. In: M. Coulthard, ed. Discussing Discourse. Birmingham: University of Birmingham, 149-167.

CAldas-Coulthard, Carmen Rosa (1988): Reporting Interaction in Narrative: A Study of Speech Presentation in Written Discourse. Unpublished Ph D. Thesis. University of Birmingham.

Culpeper, Jonathan (2001): Language and Characterisation. People in Plays and Other Texts. Harlow: Pearson Education.

Faber Benítez, Pamela and Sánchez Martínez, Jesús (1990): Semántica de prototipos: el campo semántico de los verbos que expresan la manera de hablar frente al de los verbos de sonido en inglés y español. Revista Española de Lingüística Aplicada, 6:19-29

Granger, Sylviane, Lerot Jacques and Petch-Tyson Stephanie (2003): Corpus-based Approaches to Contrastive Linguistics and Translation Studies. Amsterdam: Rodopi.

Halliday, Michael Alexander Kirkwood (2004): An Introduction to Functional Grammar. $3^{\text {rd }}$ ed. London: Arnold.

JI, Men (2012): Hypothesis testing in corpus-based literary translation studies. In: Michael P. OAKes and Men JI, eds. Quantitative Methods in Corpus-Based Translation Studies. Amsterdam: John Benjamins, 53-74. 
Kruger, Alet, Wallmach, Kim and Munday, Jeremy (2011): Corpus-Based Translation Studies: Research and Applications. London: Continuum.

Lambert, Michael. (1981): Dickens and the Suspended Quotation. New Haven: Yale University Press.

LAVIOSA, Sara (1998): The corpus-based approach: A new paradigm in translation studies. Meta. 43(4):474-479.

Laviosa, Sara (2002): Corpus-based Translation Studies: Theory, Findings, Applications. Amsterdam, New York: Rodopi B.V.

Laviosa, Sara (2011): Corpus linguistics and translation studies. In: Vander Viana, Sonia Zyngier and Geoff Barnbrook, eds. Perspectives on Corpus Linguistics. Amsterdam: John Benjamins, 131-154.

Laviosa, Sara (2013): Corpus linguistics in translation studies. In: Carmen Millán and Francesca Batrina, eds. The Routledge Handbook of Translation Studies. Abingdon: Routledge, 228-240.

Laviosa, Sara (2015): Corpora and holistic cultural translation. In: María Teresa SÁnchez Nieto, ed. Corpus-Based Translation and Interpreting Studies: From Description to Application. Berlin: Frank and Timme, 31-52.

Levin, Beth. (1993): English Verb Classes and Classifications. Chicago: The University of Chicago Press.

Mahlberg, Michaela (2013): Corpus Stylistics and Dickens's Fiction. New York/London: Routledge.

Mahlberg, Michaela, Smith, Catherine and Preston, Simon (2013): Phrases in literary contexts: Patterns and distributions of suspensions in Dickens's novels. International Journal of Corpus Linguistics. 18(1):35-56.

Martínez Vázquez, Montserrat (2003): Communicative constructions in English and Spanish. In: Cristopher S. Butler, María de los Ángeles Gómez-González and Susana M. DovalSuÁRez, eds. The Dynamics of Language Use. Amsterdam: John Benjamins, 79-109.

OAKes, Michael P. and Ji, Meng (2012): Quantitative Methods in Corpus-Based Translation Studies. Amsterdam: John Benjamins.

Patton, Jon M. and Can, Fazlin (2012): Determining translation invariant characteristics in James Joyce's Dubliners. In: Michael P. OAKes and Men JI, eds. Quantitative Methods in Corpus-Based Translation Studies. Amsterdam: John Benjamins, 209-230.

Rojo, Ana and Valenzuela, Javier (2008): How to say things with words. Ways of saying in English and Spanish. Meta. 46(3):467-477.

Ruano San Segundo, Pablo (2014): El valor caracterizador de las acotaciones en The Glass Menagerie y su traducción al español. Anuario de Estudios Filológicos. 37:215-235.

Ruano San Segundo, Pablo (forthcoming): A corpus-stylistic approach to Dickens' use of speech verbs: Beyond mere reporting. Language and Literature. 25(2).

Sánchez Nieto, María Teresa (2014): Corpus-Based Translation and Interpreting Studies: From Description to Application. Berlin: Frank and Timme.

Scarpa, Federica (2006): Corpus-Based Specialist-Translation Quality Assessment: A Study Using Parallel and Comparable Corpora in Englisj and Italian. In: Maurizio GotTi and Susan ŠARČEvić, eds. Insights into Specialised Translation. Bern: Peter Lang. 155-172.

Scotт, Mike (2013): WordSmith Tools. Version 6. Oxford. Oxford University Press.

Stockwell, Peter and Mahlberg, Michaela (2015): Mind-modelling with corpus styslistics in David Copperfield. Language and Literature. 24(2):129-147.

Wierzbicka, Anna (1987): English Speech Act Verbs: A Semantic Dictionary. Sydney: Academic Press.

XiaO, Richard (2010): Using Corpora in Contrastive and Translation Studies. Newcastle, Cambridge Scholars Publishing. 